\title{
Online Faculty Development in Low- and Middle-Income Countries for Health Professions Educators: A Rapid Realist Review
}

Lianne Keiller ( $\square$ lkeiller@sun.ac.za )

Stellenbosch University https://orcid.org/0000-0003-1597-816X

Champion Nyoni

University of the Free State Faculty of Health Sciences

Chantel van Wyk

University of the Free State Faculty of Health Sciences

\section{Research}

Keywords: Health Professions Education, Online Faculty Development, Faculty Development, Community of Practice, Educational Design Research, Conjecture Mapping, Low-and middle-income countries

Posted Date: May 5th, 2021

DOI: https://doi.org/10.21203/rs.3.rs-428797/v1

License: (c) (i) This work is licensed under a Creative Commons Attribution 4.0 International License. Read Full License 


\section{Abstract \\ Background}

Health professions educators require support to develop teaching and learning, research, educational leadership, and administrative skills to strengthen their higher education role through faculty development initiatives. Where administration has pursued face-to-face and online faculty development initiatives, results have positively influenced health professions educators. There is limited evidence demonstrating how online faculty development works for health professions educators in low- and middle-income countries who engage in online health professions education (HPE) faculty development.

\section{Methods}

A Conjecture Map for online HPE faculty development courses identified candidate theories for a rapid realist review. The Conjecture Map and candidate theories, Community of Inquiry and the Conversational Framework guided the development of search terms and analysis for this review. Three searches using EbscoHost databases yielded 1030 abstracts. A primary and secondary research team participated in a multi-reviewer blinded process in assessing abstracts, selecting full-text articles, and data extraction. The primary research team analysed eight articles for this rapid realist review to answer the research question: How do online HPE faculty development courses work, or not work, in low- and middle-income countries? Data were analysed and mapped to the initial Conjecture Map and the research question.

\section{Results}

The research references US-based organisations forming partnerships with low- and middle-income countries, and who provide funding for online HPE faculty development initiatives. These initiatives design courses that facilitate learning through engagement from which participants report beneficial outcomes of professional and career development. The review does not clarify if the reported outcomes are generalisable for facilitators from low-and middle-income countries. The findings of this review demonstrate the role of a community of practice as the dominant mechanism through which the outcomes are achieved, based on a design that incorporates six triggering events. The design aligns the triggering events with the three categories of the Community of Inquiry-a theory for designing online learning environments.

\section{Conclusion}

Health professions educators in low- and middle-income countries can develop professional and interpersonal skills through a well-designed, specifically constructed online community that prioritises active discussion.

\section{Contributions To The Literature}

- Health Professions Education faculty development research primarily represents face-to-face, institution-based initiatives situated in middle and highincome countries. The same is true for online faculty development. This influences the generalisabilty of evidence for low-and middle-income countries.

- Our study utilises an innovative approach to addressing this issue with a rapid realist review that uses Conjecture Mapping as the basis for, and output of the research. This innovation demonstrates the possibilities of combining the theoretical output of a review with the practical application of education design research.

- The findings in this study highlight the importance of local, contextually relevant, theoretically sound research.

\section{Introduction}

Faculty development is an inherently complex concept due to the nature of the interventions and the recipient context's variability, approach to delivery and purpose. Many literature, narrative and scoping reviews related to faculty development report positive programme outcomes (1) without expanding on the mechanism's complexity and operational standing to achieve these (1-4). One of these reviews specifically called for further research into online faculty development to determine what works, for whom and in what circumstances (3). This call reinforces the longstanding need to investigate the complexities inherent in online faculty development, catalysed in 2020/21 by face-to-face facilitation restrictions during the COVID-19 pandemic.

Faculty development has evolved rapidly over the last thirty years by adapting to changes in the environment, educational theory and technology (5). Globally, the literature reports that faculty development opportunities are usually institution-specific, in-person programmes or workshops for non-degree purposes, or delivered as part of a postgraduate qualification $(1,4,6,7)$. Faculty development practitioners generally claim these faculty development opportunities positively impact health professions educators $(1,4,8)$ who require support to develop their teaching and learning, research, educational leadership, and administration skills. These skills are part of the health professions educators' practice. Their development strengthens their role in higher education, especially in low- and middle-income countries where professional development opportunities are scarce (6). Theoretically sound online faculty development has the potential to positively impact the practice of health professions educators.

Educational design literature describes frameworks and guidelines grounded in theory for designing and delivering online teaching and learning (9). The Community of Inquiry, as an example, has three transactional factors that intersect to enhance the effectiveness of learning in blended and online learning environments. Two of these factors, cognitive presence and teacher presence, relate directly to the learning environment design. Learners can construct 
meaning through sustained reflection and discourse, which the teacher/facilitator meaningfully facilitates (10). Furthermore, the Conversational Framework (9) provides educators with a theoretical approach to teaching and learning in a technology-driven society. Utilising multiple learning theories, the Conversational Framework presents learning and teaching as an iterative process of generating and modulating concepts between the teacher, learner and the environment (9). A realist review (11) found the Conversational Framework to be prevalent in internet-based medical education. In this paper, the authors argue that a Community of Practice (CoP) underpinned by the Conversational Framework and Community of Inquiry is crucial for the positive outcomes of an online faculty development course for health professions educators in low- and middle-income countries.

First developed as a concept linked to social learning, CoPs consist of three dimensions; a joint enterprise, mutual engagement and a shared repertoire of communal resources focused on organisational learning (12). Two decades after Wenger's seminal work on COPs was published, Li and colleagues proposed a set of characteristics for CoPs within the health professions sector (13). These characteristics are Health professions educators who are both novices and experts in a context that supports formal and informal interaction, fostering a sense of belonging, and emphasising learning and sharing knowledge (13), closely aligns with the theoretical assertions of understanding online learning through a lens of a Community of Inquiry (10). The social, cognitive and teaching presence described in the Community of Inquiry (10) aligns with the interaction between peers and between facilitators/peers, social learning and knowledge sharing. However, the evidence for improved practice through CoPs has been limited to initiatives with explicit efforts aimed at developing communities in face-to-face or blended community environments $(4,14,15)$ middle- and high-income settings.

This paper presents a synthesis of literature with an explanatory focus aimed to unpack the mechanisms of how online faculty development work (or why they fail) in low- and middle-income countries by establishing causal relationships necessary to understand underlying mechanisms and the context in which those relationships occur.

\section{Objectives of the review}

The objective of this review was to establish the context, mechanism, and outcome (CMO) of online health professions education faculty development in lowand middle-income countries. The review question was: How do online health professions education faculty development programmes work, or not work, in low- and middle-income countries?

\section{Methods}

\section{Rapid realist review}

This study adopted a rapid realist review approach (16). This approach focuses on explaining the question under review in a time-sensitive manner instead of the lengthy, consultative approach in definitive theory-development $(16,17)$ traditionally produced in a realist review. This methodological approach addresses the call for more rigorous research related to educational technology and design research that moves beyond the "What works? questions to the deeper, theoretical and knowledge generation required for solving academic problems (18). The RAMESES publication standard (19) guided the structuring of this paper. A primary research team (the authors) and a secondary research team (independent experts in health professions education) contributed to this review.

\section{Conjecture Mapping}

The researchers initiated the rapid realist review through the development of a Conjecture Map underpinned by the pedagogical and design theories of the Conversational Framework (9) and Community of Inquiry (10). The conjecture, or hypothesis of how the proposed outcomes of an online faculty development course are achieved, served as a proposed programme theory to align with the realist review methodology(20) (Figure 1).

This Conjecture Map provided the basis for identifying the search terms, developing the data extraction tool, and analysing selected articles. To our knowledge, this has been the first rapid realist review to apply this approach.

\section{Search String}

The primary research team identified the Population, Intervention, Context and Outcome (21) (PICO), and inclusion/exclusion criteria relevant to this study. The population referred to health professions educators OR medical educators OR medical teachers OR health professions academic faculty. The interventions included were online faculty development OR technology-mediated health professions education. The context and outcomes specific to the search were lowand middle-income countries OR sub-Saharan Africa OR Africa, and professional development programmes OR faculty development.

The PICO criteria served as search terms applied to EBSCOhost databases, applying the search string to the following databases: Academic Search, Academic Search Ultimate, Africa-Wide Information, Business Source Ultimate, CAB Abstracts, CINAHL with Full Text, Communication \& Mass Media Complete, ERIC, GreenFILE, Health Source: Consumer Edition, Health Source: Nursing/Academic Edition, Humanities Source Ultimate, OpenDissertations, APA PsycArticles, APA PsycInfo, Sociology Source Ultimate, MasterFILE Premier, MEDLINE with Full Text, and Scopus. The search process was conducted in 3 phases (Additional file 1).

\section{Selection of the literature}

The following inclusion and exclusion criteria guided the selection of the articles for this review:

Inclusion criteria:

- Publication between 1 January 2010 and 1 August 2020 
- Full-text articles, commentaries and editorials published in peer-reviewed journals.

- Research reporting on online faculty development initiatives in HPE/medical education.

- Research conducted in low- and middle-income countries focused on online HPE faculty development.

- Faculty development initiatives delivered using a fully or partially online platform

Exclusion criteria:

- Studies presenting research on undergraduate student participants.

- Faculty development initiatives that do not include an online component.

- Reviews and other non-primary research

\section{Search Results}

Three searches identified 1836 citations for abstract review. One member of the primary research team manually removed all duplicates after automatic deduplication by the librarian assisting with the search. Titles and abstracts $(n=1030)$ were evaluated to confirm the primary studies' compliance with the inclusion and exclusion criteria. The primary researchers, after discussion and consensus, selected fifty abstracts for a full-text evaluation. One of the abstracts was not available to the researchers.

A secondary research team member and two primary researchers used a custom-designed tool (Additional file 2) to evaluate forty-nine full-text articles for eligibility in the review. The researchers, through a consensus-building discussion, discarded articles that did not meet the inclusion criteria. The team selected nine full-text articles for inclusion (22-30), reviewing the reference list for additional literature. However, the search did not yield additional articles. Upon further analysis, one article (22) did not meet the criteria, eliminating it from the final analysis (Figure 2).

Data extraction

Two members of the primary research team piloted the data extraction tool (Additional file 2). The first author and two secondary research team members independently extracted data from the selected full text. Data extracted included the location, facilitator and participant descriptors and recruitment, intervention, tools and materials used, outcomes of the intervention and recommendations. The first author consolidated all extracted data in a single document for analysis by the primary research team.

\section{Analysis and synthesis process}

The researchers adopted a phased analysis approach. In the first phase, each article was numerically coded for the synthesis process. The team summarised each of the selected articles to stipulate the intervention's geographical location, context, mechanism, outcomes and theoretical justification for the faculty development programmes' success or failure. The second phase consisted of an inductive thematic analysis of the CMO classifications from phase one. Finally, the researchers mapped the themes identified in the second phase of the analysis to the original Conjecture Map and candidate theories. The analysis included an inductive thematic analysis to categorise the data, map categories against candidate theories and create a draft narrative analysis of the Context, Mechanism and Outcomes. The findings of the analysis are described according to these three phases.

\section{Main Findings}

\section{Context, Mechanism and Outcome}

The $\mathrm{CMO}$ analysis yielded the following results (Table 1$)$.

Context

This review found that online faculty development initiatives, situated in low- and middle-income countries (23-30), are often offered in partnership with or through funding from US-based organisations, presented either formally or informally. Formal initiatives included postgraduate degree programmes (28), compulsory institutional programmes for staff (23), or fellowship programmes (24-27). Informal initiatives incorporated a journal club (29) or a once-off research study to investigate the rollout of an intervention for clinicians (30). Volunteer health professions educators (24-27) or peer mentors (24-26,29) within the programme itself were the primary facilitators in online faculty development $(24-27)$. Clinician researchers $(30)$ and academic staff $(23,28,29)$ facilitated online faculty development initiatives formally and informally. Participants in online faculty development programmes were academic staff or clinicians in various health profession disciplines (23-30).

\section{Mechanism}

Interventions (Table 1: Resources) within the reviewed studies made use of email discussions $(23-25,27,29)$, online forum discussions $(23,29)$ and web-based modules $(23,26,28)$. The studies also reported face-to-face workshops and training opportunities used in a blended approach to faculty development $(23,26,28)$. However, most of the studies reported on interventions centred on the use of email discussion groups $(23-25,27,29)$. The approach utilised was predominantly topic-based discussions with a focus on either research or teaching skills development topics. The data presented within the reviewed articles strongly support the use of discursive practices between participants and facilitators as key resource mechanisms for online faculty development success. 
Online faculty development opportunities had both positive and negative outcomes related to engagement. There was an increase in participation in a community of practice $(23,24,27,29)$, increased satisfaction $(23,29,30)$ and the facilitation of networking $(25-27)$. In one study $(28)$, adverse outcomes relating to engagement included difficulty in managing group dynamics and the lack of motivation of participants due to staff perceiving HPE programmes as a "bandwagon phenomenon" often linked to career progression requirements (28). There was a greater level of reporting on professional development (23,25$27,29,30$ ) than career/capacity development $(26)$, though both were outcomes of online faculty development opportunities. Where the design of a course facilitated learning in a safe, flexible and reflective learning environment $(23,25,28)$, it also enabled the enhancement of the online faculty development opportunity $(23-25,28)$ and, in some cases, the design of new programmes $(24-28,30)$. A focus, or lack thereof, on student-centred learning design resulted in positive (23-30) and negative outcomes $(25,28)$, respectively. The online faculty development opportunities were designed to deliver topical content. However, studies caution the need for awareness of online learnings' weaknesses, such as connectivity requirements and the lack of interaction created by the programmes' asynchronous nature $(25,28)$. Online faculty development opportunities required facilitators who appropriately guided participants by facilitating communication and discussion (24-30). These studies identified both the negative and positive outcomes of providing feedback or lack thereof (25,28).

\section{Thematic Outcomes}

Using an inductive thematic analysis approach, the primary research team identified thirteen relevant themes within the CMO configuration data. Themes related to the Context $(23,24,26,27,29,30)$ were the geographical location, programme type, facilitator and participant roles and responsibilities. Themes such as discussion and collaboration highlight the engagement within the Mechanism $(23-27,29,30)$ construct. In contrast, content delivery themes, self-directed learning, and evidence of competence suggested a focus on individual student activity. Finally, themes within the Outcomes (23-27,29,30) construct aligned clearly with the faculty development initiative's intended and perceived outcomes. These themes were engagement between facilitators and participants within a course, development in personal and professional domains, design of learning environments, and facilitator qualities related to course facilitation skills.

\section{Conjecture Mapping}

The final phase of the analysis consolidated the first phases with the foundational Conjecture Map and candidate theories used to set the review's objectives. The first author identified the overlap between the Conjecture Map components and the Community of Inquiry, aligning each theme with the relevant components and constructs (Table 2).

This alignment allowed the research team to refine and define the Conjecture for online health professions education faculty development in low- and middleincome countries. This educational design tool is now a potential research catalyst for faculty developers (Figure 3).

\section{Discussion}

This rapid realist review used a Conjecture Map developed with the Conversational Framework and Community of Inquiry as the theoretical basis for online health professions education faculty development courses' design considerations. The findings of the review partially supported selecting these candidate theories, specifically the Community of Inquiry, as underpinning asynchronous online learning. The programme theory was not reliant on the technical or design considerations of online faculty development for health professions educators, which would have supported the Conversational Framework as a core theory influencing course design. The Conversational Framework provides the parameters from which to assess the role of using feedback from the learning environment, the student and between students to adapt the design of the learning environment (9). Further confirmation of the appropriate candidate theories emanated from three articles that reported a theoretical framework for evaluating their faculty development opportunity $(24,26,28)$, two of which incorporated the Community of Inquiry into the design and evaluation of their faculty development opportunity $(24,28)$. The third article applied the Kirkpatrick evaluation model to their study (26). This outcome, paired with the CMO analysis, implies that the mechanism through which faculty development outcomes in low-and middle income countries are achieved may be due to creating a community of educators, thus answering the "Why online faculty development courses in Lowand middle-income countries work?".

The existence or development of a community of educators facilitates collaborative learning within higher education (10). In the context of faculty development, this review demonstrates the validity of interrogating the effectiveness of designing interventions through the lens of a community of practice (4). This community should be focused on capacity development through collaborative learning and practice(26). Furthermore, research has shown that faculty development should adopt an approach in which a community of practice is a critical outcome (31) in face-to-face and online initiatives (3).

Similar to earlier research identifying a positive correlation between cognitive presence and community (32), this review found that the positive developmental outcomes within well-designed, purpose-driven online courses consistently relied on the domains and categories that align with the Community of Inquiry and a Community of Practice. When an online course creates "cognitive dissonance", the Community of Inquiry posits that this acts as a triggering event for cognitive development (8). In the process of theory building within this review, the authors found that the "triggering event" aligned with the Cognitive Presence in the Community of Inquiry is not specifically the existence of a sense of puzzlement (33), but rather the creation or existence of a Community of Practice. Aligning the themes-the Conjecture Map, the CMO configurations and the Community of Inquiry-highlights the recurrence of the teacher and cognitive presence constructs in these interventions.

This review identified six triggering events as critical in developing a community of practice in an online faculty development course for health professions educators in low- and middle-income countries. These are programme type, programme design, discussion, engagement, development, and collaboration. These events align with the Conjecture Map, predominantly within the embodiment of the course, outlining the salient design principles that include the tools, 
activities, materials, participant structures and discursive practices. Each of these either creates a "common ground for sharing knowledge", "a social structure for interactions", or creates and curates "specific knowledge shared, developed and maintained by the community (4)." Utilising the Community of Practice as a lens through which to analyse the design and theoretical conjectures for online health professions education courses is supported through the intended application of this theory (34) (Table 3)

The authors answered the "what works, in what context, and why it works" within this review. In the light of these, the authors interrogated the data to identify "for whom" these initiatives work effectively. Considering the original intention of this review and efforts to ensure an approach to design and delivery of noninstitutional online health professions education faculty development opportunities specifically for the low- and middle-income country context, there is a question of whether the foreign gaze (35) evident within the data is necessary for achieving the presented outcomes.

Literature and reviews have raised the notion of the foreign gaze in the context of Global Health (35). Despite this, faculty development for health professions educators focuses primarily on developed countries (6). The question that the finding of this review raises is whether this can be attributed to publications that are more likely to emanate from a foreign gaze perspective, assuming what works in low- and middle-income countries. The reviewed articles were primarily US-based in origin, ownership of the intervention or authorship profile. While the authors concede that the triggering event of programme type could be an internationally funded and resourced intervention, the question is whether the foreign gaze is a necessary catalyst for developing the resultant online community in a low- and middle-income context. Faculty development initiatives in Africa have incorporated communities of practice as a capacity development opportunity (36). However, in the study presenting this finding, US funding was relied on in a "partnership", calling into question cultural alignment with the recipients' needs at the inception of the programme (2). The answer to the question relating to "for whom? online health professions education faculty development courses work indicates educators and clinical educators as the recipients. This review cannot unequivocally state that this is true for facilitators from low- and middle-income countries, as the facilitators in all studies were a combination of both local and foreign.

As an outcome of this rapid realist review, the programme theory generated is that "health professions educators in low- and middle-income countries (context) can develop professional and inter-personal skills (outcome) through a well-designed, specifically constructed online community that prioritises active discussion (mechanism)".

\section{Strengths, limitations and future research recommendations}

This review's design followed an iterative process with multiple blinded reviewers across a primary and secondary research team. Each component of the structured approach $(19,20)$ adopted by the research teams was documented and reviewed throughout the analysis phase. The design and process employed demonstrate the rigour applied to the review, limiting the bias and potential gaps that the authors may have encountered. Additionally, initiating this review by utilising a Conjecture Map to integrate the educational and theoretical focus as the subject under investigation further strengthens the study. The limitation of this study was the absence of an initial consultative process with the health professions education community members to identify candidate theories, as is dictated through the original realist review methodology (20). As a mitigation strategy for this limitation, the authors sought input on the study protocol from health professions educators at two higher education institutions in South Africa. The authors recognise the limitation that English papers accessed through a single university library in South Africa could limit the number of citations that may have met the inclusion criteria. However, this library had access to popular databases. The reviewed articles' quality and theoretical contribution are not uncommon in online education literature and require higher quality standards in the research conducted $(1-4,18)$. The use of a Conjecture Map supports an approach to strengthening this and future research on the theoretically grounded design of online health professions education faculty development courses (37).

Future research should include more comprehensive consultation across health professions educators to investigate the reliability and feasibility of these findings about the design and delivery of online health professions education faculty development in low- and middle-income countries.

\section{Conclusion}

This rapid realist review aimed to answer how online health professions education faculty development courses work or do not work in low- and middleincome countries. The approach to executing this review highlights the possibilities of integrating educational design research tools for the development of candidate theories and the realist review approach. This review's findings demonstrate the community's role as the dominant mechanism through which these interventions work, based on a design that incorporates six triggering events. The study aligns these events with the three categories of the Community of Inquiry, a theory applicable to the design of online learning environments. Health professions educators in low- and middle-income countries can develop professional and interpersonal skills through a well-designed, specifically constructed online community that prioritises active discussion. Finally, this rapid realist review highlights deficiencies in the quantity publications and the influence of a foreign gaze on the evidence available within this field. As part of a larger research project, this study supports our final recommendation that further research is required to contextualise these findings through a consultative process to develop a model for designing and delivering online health professions education faculty development courses within a low-and middle-income setting.

\section{Abbreviations}

HPE: Health Professions Education

CoP: Community of Practice

CMO: Context, Mechanism, Outcome

Online HPE-FD: Online Health Professions Education Faculty Development 
PICO: Population, Intervention, Context and Outcome

LMIC: Low-and middle-income countries

US: United States of America

\section{Declarations}

\section{Ethics approval and consent to participate:}

Ethics approval for this study was granted by The University of the Free State (HSRD 20201516/2411). Written consent to participate was received from each member of the secondary research team.

\section{Consent for publication:}

Not applicable

\section{Availability of supporting data:}

Relevant data and materials have been provided as Additional Files 1 and 2, referenced in the manuscript.

\section{Competing interests:}

The authors declare they have no competing interests.

\section{Funding:}

This research was self-funded by the authors.

\section{Authors' contributions:}

LK, CN and CVW designed the study. LK adopted the lead role in data collection and analysis, assisted by CN. CVW contributed to the analysis of the data to reach the presented conclusions. All authors contributed to the drafting of the manuscript.

\section{Acknowledgements}

The authors wish to acknowledge the secondary research team: Prof D Manning, Prof W Cordier and Ms A Dreyer for their contributions to the study. The authors thank Drs Graham and Joynes for their invaluable input as critical readers, and Dr du Preez for his editing services in the preparation of this manuscript.

\section{References}

1. Behar-Horenstein L, Kuang H, Tolentino L, Zhang H. Faculty Development in the Health Professions: A Review of the Literature. Journal of Faculty Development. 2019;33(2):77-96.

2. Lewis LD, Steinert Y. How Culture Is Understood in Faculty Development in the Health Professions: A Scoping Review. Acad Med. 2020;95(2):310-9.

3. Cook DA, Steinert Y. Online learning for faculty development: A review of the literature. Med Teach. 2013;35(11):930-7.

4. Abigail LKM. Do communities of practice enhance faculty development? Health Professions Education [Internet]. 2016;2(2):61-74. Available from: http://dx.doi.org/10.1016/j.hpe.2016.08.004.

5. Bilal, Guraya SY, Chen S. The impact and effectiveness of faculty development program in fostering the faculty's knowledge, skills, and professional competence: A systematic review and meta-analysis. Saudi Journal of Biological Sciences [Internet]. 2019;26(4):688-97. Available from: https://doi.org/10.1016/j.sjbs.2017.10.024.

6. Cilliers FJ, Tekian A. Effective Faculty Development in an Institutional Context: Designing for Transfer. Journal of Graduate Medical Education. 2016;8(2):145-9.

7. Tekian A, Harris I. Preparing health professions education leaders worldwide: A description of masters-level programs. Med Teach. 2012;34(1):52-8.

8. Vaughan N, Garrison R. A blended faculty community of inquiry: Linking leadership, course redesign, and evaluation. Canadian Journal of University Continuing Education. 2006;32(2):67-92.

9. Laurillard D. Teaching as a Design Science: Building Pedagogical patterns for learning and technology. London: Routledge. London, UK: Routeledge Farmer;; 2012.

10. Garrison DR, Arbaugh JB. Researching the community of inquiry framework: Review, issues, and future directions. Internet Higher Education. 2007;10(3):157-72.

11. Wong G, Greenhalgh T, Pawson R. Internet-based medical education: a realist review of what works, for whom and in what circumstances. BMC medical education. 2010;10:12.

12. Wenger E. Communities of Practice: Learning as a Social System. 1998;(June):1-10. 
13. Li LC, Grimshaw JM, Nielsen C, Judd M, Coyte PC, Graham ID. Evolution of Wenger's concept of community of practice. Implementation science: IS [Internet]. 2009 Jan [cited 2012 Jul 13];4:11. Available from: http://www.pubmedcentral.nih.gov/articlerender.fcgi? artid=2654669\&tool=pmcentrez\&rendertype=abstract.

14. Vaughan N, Garrison R. How Blended Learning Can Support a Faculty Development Community of Inquiry. Online Learning [Internet]. 2019;10(4). Available from: https://olj.onlinelearningconsortium.org/index.php/olj/article/view/1750.

15. Garrison DR. Online Community of Inquiry Review: Social, Cognitive, and Teaching Presence Issues. Journal of Asynchronous Learning Networks. 2007;11(1):61-72.

16. Saul JE, Willis CD, Bitz J, Best A. A time-responsive tool for informing policy making: Rapid realist review. Implementation Science. 2013;8(1):1-15.

17. Tsang JY, Blakeman T, Hegarty J, Humphreys J, Harvey G. Understanding the implementation of interventions to improve the management of chronic kidney disease in primary care: A rapid realist review. Implementation Science [Internet]. 2016;11(1):1-16. Available from: http://dx.doi.org/10.1186/s13012-016-0413-7.

18. Reeves TC, Lin L. The research we have is not the research we need. Educational Technology Research and Development [Internet]. 2020;68(4):19912001. Available from: https://doi.org/10.1007/s11423-020-09811-3.

19. Wong G, Greenhalgh T, Westhorp G, Buckingham J, Pawson R. RAMESES publication standards: Meta-narrative reviews. J Adv Nurs. 2013;69(5):9871004.

20. Pawson R, Greenhalgh T, Harvey G, Walshe K. Realist Review - a new method of systematic review designed for complex policy interventions. Journal of Health Services Research Policy. 2005;10(1):21-34.

21. Cook DA, West CP. Conducting systematic reviews in medical education: A stepwise approach. Med Educ. 2012;46(10):943-52.

22. Vovides Y, Chale SB, Gadhula R, Kebaetse MB, Nigussie NA, Suleman F, et al. A Systems approach to implementation of elearning in medical education: Five MEPI Schools' Journeys. Acad Med. 2014;89(8 SUPPL.):102-6.

23. Ahmed S. Tailoring online faculty development programmes: overcoming faculty resistance. Medical education. 2013;47(5):535.

24. Anshu, Sharma M, Burdick WP, Singh T. Group dynamics and social interaction in a south asian online learning forum for faculty development of medical teachers. Education for Health: Change in Learning Practice. 2010;23(1):1-9.

25. Dongre AR, Chacko TV, Banu S, Bhandary S, Sahasrabudhe RA, Philip S, et al. On-line capacity-building program on 'Analysis of Data' for medical educators in the South Asia region: A qualitative exploration of our experience. Education for Health: Change in Learning and Practice. 2010;23(3).

26. Frantz JM, Bezuidenhout J, Burch VC, Mthembu S, Rowe M, Tan C, et al. The impact of a faculty development programme for health professions educators in sub-Saharan Africa: An archival study. BMC Med Educ. 2015;15(1):1-9.

27. Ladhani Z, Health C, College S. Online role-playing for faculty development. Clin Teach. 2011;8:31-6.

28. Naeem N. Khan K. RA. Stuck in the blend: Challenges faced by students enrolled in blended programs of Masters in Health Professions Education. Pakistan Journal of Medical Sciences. 2019;35(4):929-33.

29. Thakurdesai A, Ghosh A, Menon V, Sahoo S, Tripathi A, Harshe D, et al. Electronic journal clubs for capacity building: A case study in psychiatry as a model for medical disciplines in developing countries. Asian Journal of Psychiatry [Internet]. 2018;34(April 2018):93-7. Available from:

https://doi.org/10.1016/j.ajp.2018.04.026.

30. Woods D, Attwell A, Ross K, Theron G. Text messages as a learning tool for midwives. South African Medical Journal. 2012;102(2):100-1.

31. de Carvalho-Filho MA, Tio RA, Steinert Y. Twelve tips for implementing a community of practice for faculty development. Medical Teacher [Internet]. 2018;1-7. Available from: https://doi.org/10.1080/0142159X.2018.1552782.

32. Garrison DR, Cleveland-Innes M. Facilitating Cognitive Presence in Online Learning: Interaction Is Not Enough. Int J Phytorem. 2005;21(1):133-48.

33. Pool J. An investigation of Communities of Inquiry within a blended mode of delivery for technology education. North West University; 2014.

34. O'Brien BC, Battista A. Situated learning theory in health professions education research: a scoping review. Advances in Health Sciences Education [Internet]. 2019; Available from: https://doi.org/10.1007/s10459-019-09900-w.

35. Abimbola S. The foreign gaze: Authorship in academic global health. BMJ Global Health. 2019;4(5):1-5.

36. Frantz J, Rhoda A, Murdoch-Eaton DB, Sandars J, Marshall M, Burch VC. Understanding faculty development as capacity development: A case study from South Africa. African Journal of Health Professions Education [Internet]. 2019;11(2):53. Available from:

http://www.ajhpe.org.za/index.php/ajhpe/article/view/1026.

37. Wozniak H. Conjecture mapping to optimize the educational design research process. Australasian Journal of Educational Technology. 2015;31(5):597612.

\section{Tables}

Table 1: CMO Analysis 


\begin{tabular}{|c|c|c|c|c|c|c|}
\hline Code & Title & Country & Context & $\begin{array}{l}\text { Mechanism } \\
\text { (Resource) }\end{array}$ & $\begin{array}{l}\text { Mechanism } \\
\text { (Reasoning/Why) }\end{array}$ & Outcome \\
\hline 1 & $\begin{array}{l}\text { Ahmed (2013) Tailoring online } \\
\text { faculty development } \\
\text { programmes: overcoming } \\
\text { faculty resistanceReference: } \\
23\end{array}$ & Egypt & $\begin{array}{l}\text { Invited Expert } \\
\text { Ophthalmology } \\
\text { \& Vascular surgery } \\
\text { clinician and faculty } \\
\text { facilitators and } \\
\text { participants }\end{array}$ & $\begin{array}{l}\text { Participant selects } \\
\text { learning needs via } \\
\text { email invitation, } \\
\text { custom designed } \\
\text { online } \\
\text { course, Assignments } \\
\text { and expert-led } \\
\text { discussions, } \\
\text { f2f workshop }\end{array}$ & $\begin{array}{l}\text { External expert } \\
\text { involvement and self- } \\
\text { directed } \\
\text { learning improved } \\
\text { participation and } \\
\text { satisfaction, decreased } \\
\text { resistance }\end{array}$ & $\begin{array}{l}\text { Increased } \\
\text { participation, } \\
\text { Participant } \\
\text { satisfaction }\end{array}$ \\
\hline 2 & $\begin{array}{l}\text { Anshu, Sharma, Burdick \& } \\
\text { Singh (2010) Group Dynamics } \\
\text { and Social Interaction in a } \\
\text { South Asian Online Learning } \\
\text { Forum for } \\
\text { Faculty Development of } \\
\text { Medical Teachers } \\
\text { Reference: } 24\end{array}$ & India & $\begin{array}{l}\text { Fellows \& Fellow- } \\
\text { moderators in HPE } \\
\text { fellowship programme } \\
\text { and facilitators for } \\
\text { programme. }\end{array}$ & $\begin{array}{l}\text { Email listServe } \\
\text { discussion on topic } \\
\text { selected } \\
\text { by participants and } \\
\text { facilitated by near- } \\
\text { peers with faculty } \\
\text { mentoring of the } \\
\text { moderators. }\end{array}$ & $\begin{array}{l}\text { community of inquiry } \\
\text { (Social Presence) } \\
\text { supported } \\
\text { by involvement of } \\
\text { moderators supports } \\
\text { learner-centred } \\
\text { design and } \\
\text { modification of } \\
\text { curriculum activities }\end{array}$ & $\begin{array}{l}\text { High level of social } \\
\text { presence supporting } \\
\text { cognitive and } \\
\text { teacher presence for } \\
\text { promoting ongoing } \\
\text { discussion to engage } \\
\text { with topic. }\end{array}$ \\
\hline 3 & $\begin{array}{l}\text { Dongre, Chacko, Banu, } \\
\text { Bhandary, Sahasrubudhe, } \\
\text { Philip \& Deshmukh (2010) On- } \\
\text { line Capacity-Building Program } \\
\text { on "Analysis of Data" for } \\
\text { Medical Educators in the } \\
\text { South Asia Region: A } \\
\text { Qualitative Exploration of } \\
\text { our ExperienceReference: } 25\end{array}$ & $\begin{array}{l}\text { India, } \\
\text { Nepal, } \\
\text { Malaysia }\end{array}$ & $\begin{array}{l}\text { Fellows \& Fellow- } \\
\text { moderators in HPE } \\
\text { fellowship programme } \\
\text { and facilitators for } \\
\text { programme. }\end{array}$ & $\begin{array}{l}\text { Email listServe } \\
\text { discussion on } \\
\text { research methods } \\
\text { to support Fellows in } \\
\text { conducting HPE } \\
\text { innovation research. }\end{array}$ & $\begin{array}{l}\text { Adult learning } \\
\text { principles that supports } \\
\text { a flexible, } \\
\text { reactive learning } \\
\text { environment. }\end{array}$ & $\begin{array}{l}\text { Discussion provided } \\
\text { support in study } \\
\text { design, } \\
\text { implementation and } \\
\text { analysis plans and } \\
\text { production of } \\
\text { technically robust } \\
\text { research work. Email } \\
\text { discussion highlighted } \\
\text { learning needs and } \\
\text { helped shape the } \\
\text { learning outcomes for } \\
\text { the group. }\end{array}$ \\
\hline 4 & $\begin{array}{l}\text { Frantz, Bezuidenhout, Burch, } \\
\text { Mthembu, Rowe, Tan, Van Wyk } \\
\text { \& Van Heerden (2015) } \\
\text { The impact of a faculty } \\
\text { development programme for } \\
\text { health professions educators } \\
\text { in sub-Saharan Africa: an } \\
\text { archival study Reference: } 26\end{array}$ & $\begin{array}{l}\text { South } \\
\text { Africa }\end{array}$ & $\begin{array}{l}\text { Fellows in HPE } \\
\text { fellowship programme } \\
\text { and HPE } \\
\text { expert facilitators for } \\
\text { programme. }\end{array}$ & $\begin{array}{l}2 \text { year blended } \\
\text { fellowship } \\
\text { programme. } 3 \text { f2f } \\
\text { sessions with } \\
\text { workshops on } \\
\text { scholarship, } \\
\text { project management, } \\
\text { teaching and } \\
\text { leadership. Online } \\
\text { / distance learning } \\
\text { sessions. }\end{array}$ & $\begin{array}{l}\text { A broad, context- } \\
\text { sensitive knowledge of } \\
\text { HPE as well } \\
\text { as excellent teaching } \\
\text { and research skills to } \\
\text { run such } \\
\text { programmes facilitates } \\
\text { the outcomes identified } \\
\text { meeting Kirkpatrick } \\
\text { Model of evaluation } \\
\text { levels. }\end{array}$ & $\begin{array}{l}\text { (1) belonging to a } \\
\text { community of } \\
\text { practice, (2) } \\
\text { personal development, } \\
\text { (3) professional } \\
\text { development, (4) use } \\
\text { of tools and strategies } \\
\text { for project } \\
\text { management and/or } \\
\text { advancement, and (5) } \\
\text { capacity development }\end{array}$ \\
\hline 5 & $\begin{array}{l}\text { Ladhani, Chatwal, Vyas, Iqbal, } \\
\text { Tan \& Diserens (2011) Online } \\
\text { role-playing for } \\
\text { faculty developmentReference: } \\
27\end{array}$ & $\begin{array}{l}\text { Pakistan } \\
\text { India } \\
\text { Malaysia } \\
\text { USA }\end{array}$ & $\begin{array}{l}\text { Fellows \& Fellow- } \\
\text { moderators in HPE } \\
\text { fellowship programme } \\
\text { and facilitators for } \\
\text { programme. }\end{array}$ & $\begin{array}{l}\text { Role-playing } \\
\text { scenario sent via } \\
\text { email listServe } \\
\text { focused on CBME as } \\
\text { theoretical topic. } \\
\text { Participants } \\
\text { required to use } \\
\text { available materials } \\
\text { on the topic to } \\
\text { respond to a } \\
\text { fictitious Dean's } \\
\text { letter as various } \\
\text { stakeholders. }\end{array}$ & $\begin{array}{l}\text { Adult learning and } \\
\text { online role-playing: } \\
\text { Encouraged } \\
\text { distributed participation } \\
\text { among a diverse } \\
\text { population, keeping } \\
\text { participation and } \\
\text { interest high due to the } \\
\text { role-playing approach } \\
\text { used. }\end{array}$ & $\begin{array}{l}\text { The discussion } \\
\text { helped to clarify } \\
\text { concepts related } \\
\text { to CBME, } \\
\text { and generated many } \\
\text { themes; } 10 \text { models of } \\
\text { CBME from } \\
\text { various countries. The } \\
\text { active participation } \\
\text { and high level of } \\
\text { engagement had an } \\
\text { impact on subsequent } \\
\text { online discussions on } \\
\text { the list server. role- } \\
\text { playing was picked up } \\
\text { and used in the } \\
\text { virtual session } \\
\text { discussions by the } \\
\text { fellows in one of } \\
\text { FAIMER's } \\
\text { four regional } \\
\text { institutes. This re-use } \\
\text { of the learning } \\
\text { strategy by } \\
\text { other fellows (health } \\
\text { professions faculty } \\
\text { members) is probably } \\
\text { the best evidence that } \\
\text { this group finds role-- } \\
\text { playing to be } \\
\text { effective and } \\
\text { 6enjoyable for the } \\
\text { participants. }\end{array}$ \\
\hline 6 & $\begin{array}{l}\text { Naeem \& Khan (2019) Stuck in } \\
\text { the blend: Challenges faced by } \\
\text { students enrolled in blended } \\
\text { programs of Masters in } \\
\text { Health Professions Education }\end{array}$ & Pakistan & $\begin{array}{l}\text { Masters (HPE) } \\
\text { students } \\
\text { and internal/external } \\
\text { teaching faculty. }\end{array}$ & $\begin{array}{l}\text { Blended MHPE } \\
\text { programme using } \\
\text { both f2f and } \\
\text { online activities }\end{array}$ & $\begin{array}{l}\text { Constructivist and } \\
\text { collaborative learning } \\
\text { approach } \\
\text { used. Community of } \\
\text { inquiry used to analyse. } \\
\text { Issues identified }\end{array}$ & $\begin{array}{l}\text { Students struggled to } \\
\text { develop autonomy, } \\
\text { were overloaded on } \\
\text { a cognitive level and } \\
\text { required facilitators to } \\
\text { actively }\end{array}$ \\
\hline
\end{tabular}




\begin{tabular}{|c|c|c|c|c|c|c|}
\hline & Reference: 28 & & & & $\begin{array}{l}\text { where learner presence } \\
\text { was negatively } \\
\text { influenced by issues } \\
\text { related to self- } \\
\text { regulation and as a } \\
\text { result of previous } \\
\text { experience as spoon- } \\
\text { fed learners. } \\
\text { Infrastructure and } \\
\text { internet access } \\
\text { negatively influenced } \\
\text { student experience and } \\
\text { participation. }\end{array}$ & $\begin{array}{l}\text { manage group } \\
\text { dynamics with a } \\
\text { group who struggled } \\
\text { with } \\
\text { time management as } \\
\text { a result of work- } \\
\text { requirements. Lack of } \\
\text { support from } \\
\text { institution also } \\
\text { negatively influenced } \\
\text { student } \\
\text { participation and } \\
\text { success of the } \\
\text { programme. }\end{array}$ \\
\hline 7 & $\begin{array}{l}\text { Thakurdesai, Ghosh, Menon, } \\
\text { Sahoo, Tripathi, Harshe \& } \\
\text { Andrade (2018) Electronic } \\
\text { journal clubs for capacity } \\
\text { building: A case study } \\
\text { in psychiatry as a model for } \\
\text { medical disciplines } \\
\text { in developing countries } \\
\text { Reference: } 29\end{array}$ & India & $\begin{array}{l}\text { Psychiatrists (post- } \\
\text { graduate students, } \\
\text { recent } \\
\text { graduates, academic } \\
\text { faculty and clinicians) }\end{array}$ & $\begin{array}{l}\text { Electronic journal } \\
\text { club for discussion } \\
\text { of articles, training } \\
\text { on manuscript } \\
\text { review and scholarly } \\
\text { analysis and writing. }\end{array}$ & $\begin{array}{l}\text { Can be replicated in } \\
\text { other developing } \\
\text { countries for } \\
\text { more efficient } \\
\text { manpower } \\
\text { development and } \\
\text { capacity building } \\
\text { in academic medicine. } \\
\text { The availability of } \\
\text { active, } \\
\text { committed, competent, } \\
\text { and experienced } \\
\text { facilitators is needed. }\end{array}$ & $\begin{array}{l}\text { Improved analytical } \\
\text { and as well as writing } \\
\text { skills. } \\
\text { Opportunities for } \\
\text { participation in } \\
\text { research projects. } \\
\text { Publications. } \\
\text { Collectively seen as } \\
\text { improved scholarship } \\
\text { skills. }\end{array}$ \\
\hline 8 & $\begin{array}{l}\text { Woods, Attwell, Ross, Theron } \\
\text { (2012) Text messages a } \\
\text { learning tool for midwives } \\
\text { Reference: } 30\end{array}$ & $\begin{array}{l}\text { South } \\
\text { Africa }\end{array}$ & $\begin{array}{l}\text { Midwives in clinical } \\
\text { practice supported by } \\
\text { Perinatal } \\
\text { education programme } \\
\text { staff. }\end{array}$ & $\begin{array}{l}\text { Short essential } \\
\text { learning text } \\
\text { messages with links } \\
\text { to coursework sent } \\
\text { to participants. }\end{array}$ & $\begin{array}{l}\text { Cost-effective and } \\
\text { relevant clinical-content } \\
\text { of messages } \\
\text { was useful to those in } \\
\text { both private and public } \\
\text { sector, urban and rural } \\
\text { setting. }\end{array}$ & $\begin{array}{l}\text { Participant } \\
\text { enjoyment, improved } \\
\text { their clinical practice, } \\
\text { regular sharing and } \\
\text { discussions about the } \\
\text { messages with } \\
\text { colleagues. Cost- } \\
\text { effective learning } \\
\text { opportunities, which } \\
\text { can contribute } \\
\text { to student teaching in } \\
\text { clinical setting. }\end{array}$ \\
\hline
\end{tabular}

Table 2: Overlap of CMO, Candidate Theory and Conjecture Map

\begin{tabular}{|llll|}
\hline Community of Inquiry & Conjecture Map & Theme & CMO \\
\hline Cognitive Presence & Embodiment & Geographical & Context \\
\hline Teacher Presence & Embodiment & Programme type & Context \\
\hline Teacher Presence & Embodiment & Facilitator & Context \\
\hline Social presence & Embodiment & Participant & Context \\
\hline Cognitive, Social \& Teacher Presence & Embodiment \& Mediating Processes & Discussion & Mechanism \\
\hline Social \& Cognitive Presence & Embodiment \& Mediating Processes & Collaboration & Mechanism \\
\hline Cognitive \& Teacher Presence & Embodiment \& Mediating Processes & Self-directed learning & Mechanism \\
\hline Teacher Presence & Embodiment \& Mediating Processes & Content delivery & Mechanism \\
\hline Cognitive \& Teacher Presence & Embodiment \& Mediating Processes & Evidence of competence & Mechanism \\
\hline Social \& Teacher Presence & Embodiment \& Outcome & Engagement & Outcome \\
\hline Cognitive Presence & Outcome & Development & Outcome \\
\hline Cognitive, Social \& Teacher Presence & Embodiment \& Outcome & Design & Outcome \\
\hline Teacher Presence & Embodiment & Facilitator Qualities & Outcome \\
\hline
\end{tabular}

Table 3: Alignment of triggering events with $\mathrm{CMO}$ 


\begin{tabular}{|c|c|c|c|c|c|c|}
\hline & Context & & Mechanism & & Outcome & \\
\hline Article & $\begin{array}{l}\text { Geographical } \\
\text { Consideration }\end{array}$ & $\begin{array}{l}\text { Programme } \\
\text { Type }\end{array}$ & Discussion & Collaboration & Engagement & Development \\
\hline $\begin{array}{l}\text { Ahmed (2013) Tailoring online faculty development } \\
\text { programmes: overcoming faculty resistance }\end{array}$ & $\sqrt{ }$ & $\sqrt{ }$ & $\sqrt{ }$ & $\sqrt{ }$ & $\sqrt{ }$ & $\sqrt{ }$ \\
\hline $\begin{array}{l}\text { Anshu, Sharma, Burdick \& Singh (2010) Group Dynamics } \\
\text { and Social Interaction in a South Asian Online Learning } \\
\text { Forum for Faculty Development of Medical Teachers }\end{array}$ & $\sqrt{ }$ & $\sqrt{ }$ & $\sqrt{ }$ & $\sqrt{ }$ & $\sqrt{ }$ & $\sqrt{ }$ \\
\hline $\begin{array}{l}\text { Dongre, Chacko, Banu, Bhandary, Sahasrubudhe, Philip \& } \\
\text { Deshmukh ( } 2010) \text { On-line Capacity-Building Program on } \\
\text { "Analysis of Data" for Medical Educators in the South } \\
\text { Asia Region: A Qualitative Exploration of our Experience }\end{array}$ & $\sqrt{ }$ & $\sqrt{ }$ & $\sqrt{ }$ & $\sqrt{ }$ & $\sqrt{ }$ & $\sqrt{ }$ \\
\hline $\begin{array}{l}\text { Frantz, Bezuidenhout, Burch, Mthembu, Rowe, Tan, Van } \\
\text { Wyk \& Van Heerden (2015) The impact of a faculty } \\
\text { development programme for health professions } \\
\text { educators in sub-Saharan Africa: an archival study }\end{array}$ & $\sqrt{ }$ & $\sqrt{ }$ & $\sqrt{ }$ & $\sqrt{ }$ & $\sqrt{ }$ & $\sqrt{ }$ \\
\hline $\begin{array}{l}\text { Ladhani, Chhatwal, Vyas, Iqbal, Tan \& Diserens (2011) } \\
\text { Online role-playing for faculty development }\end{array}$ & $\sqrt{ }$ & $\sqrt{ }$ & $\sqrt{ }$ & $\sqrt{ }$ & $\sqrt{ }$ & $\sqrt{ }$ \\
\hline $\begin{array}{l}\text { Naeem \& Khan (2019) Stuck in the blend: Challenges } \\
\text { faced by students enrolled in blended programs of } \\
\text { Masters in Health Professions Education }\end{array}$ & $\sqrt{ }$ & $\sqrt{ }$ & $\sqrt{ }$ & $\sqrt{ }$ & & \\
\hline $\begin{array}{l}\text { Thakurdesai, Ghosh, Menon, Sahoo, Tripathi, Harshe \& } \\
\text { Andrade (2018) Electronic journal clubs for capacity } \\
\text { building: A case study in psychiatry as a model for } \\
\text { medical disciplines in developing countries }\end{array}$ & $\sqrt{ }$ & $\sqrt{ }$ & $\sqrt{ }$ & $\sqrt{ }$ & $\sqrt{ }$ & $\sqrt{ }$ \\
\hline $\begin{array}{l}\text { Woods, Attwell, Ross, Theron (2012) Text messages a } \\
\text { learning tool for midwives }\end{array}$ & $\sqrt{ }$ & $\sqrt{ }$ & & & $\sqrt{ }$ & $\sqrt{ }$ \\
\hline
\end{tabular}

\section{Figures}

Design Conjectures

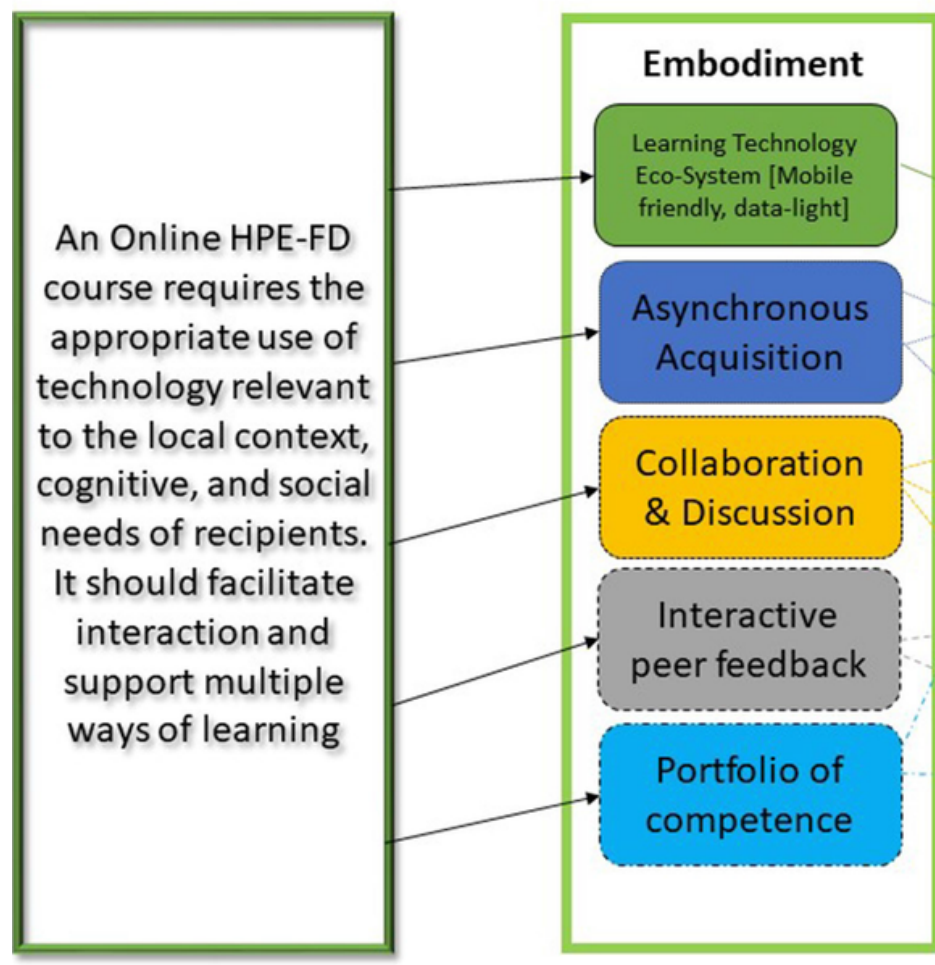

Theoretical Conjectures

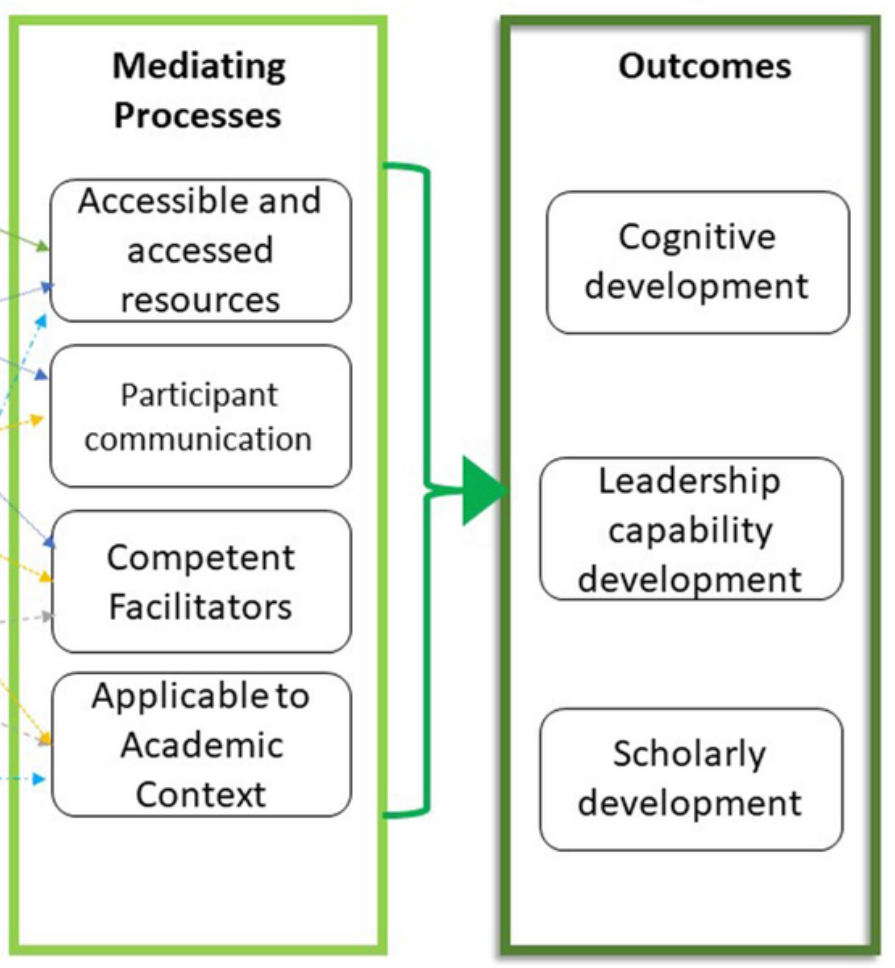


Preliminary Conjecture Map

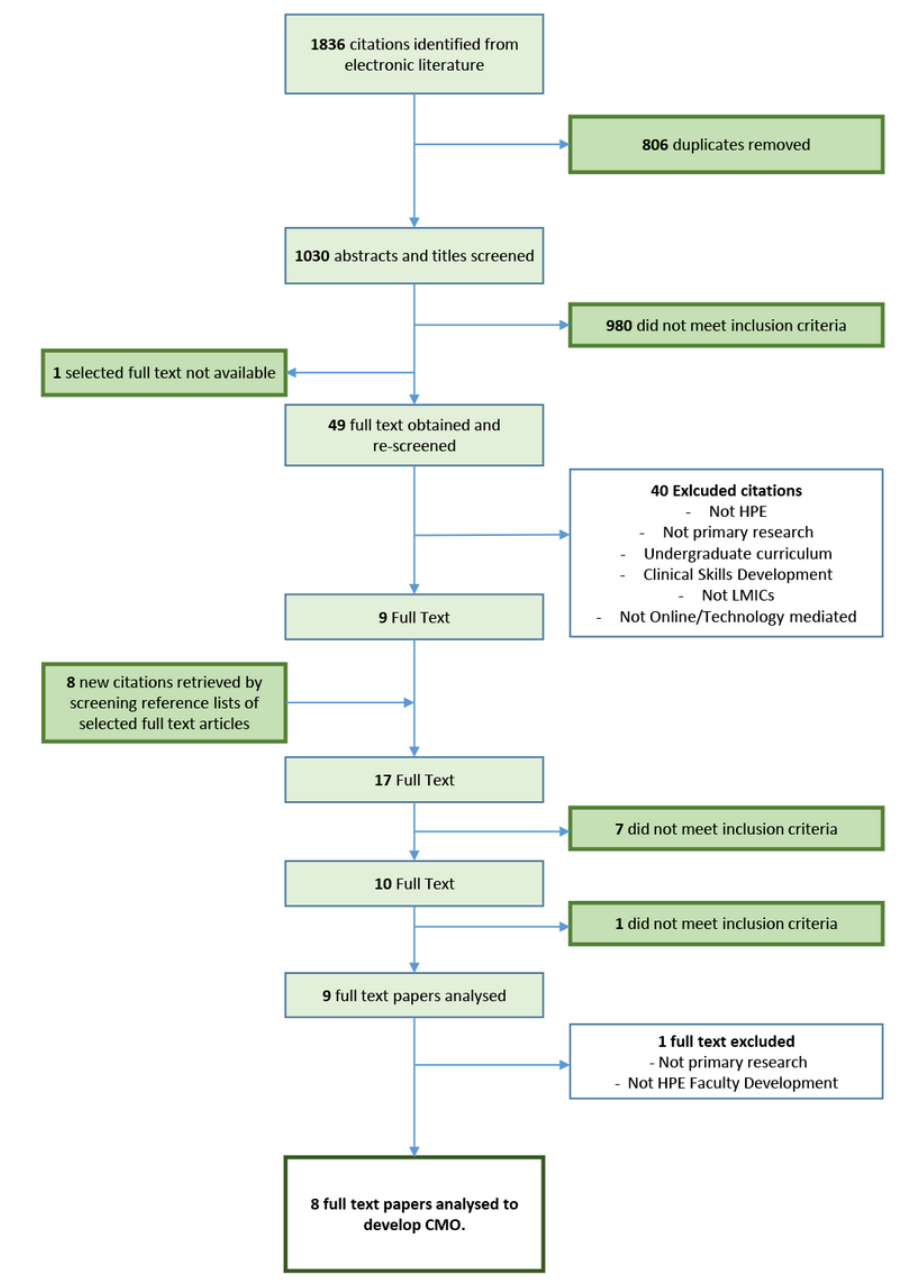

Figure 2

PRISMA flowchart 


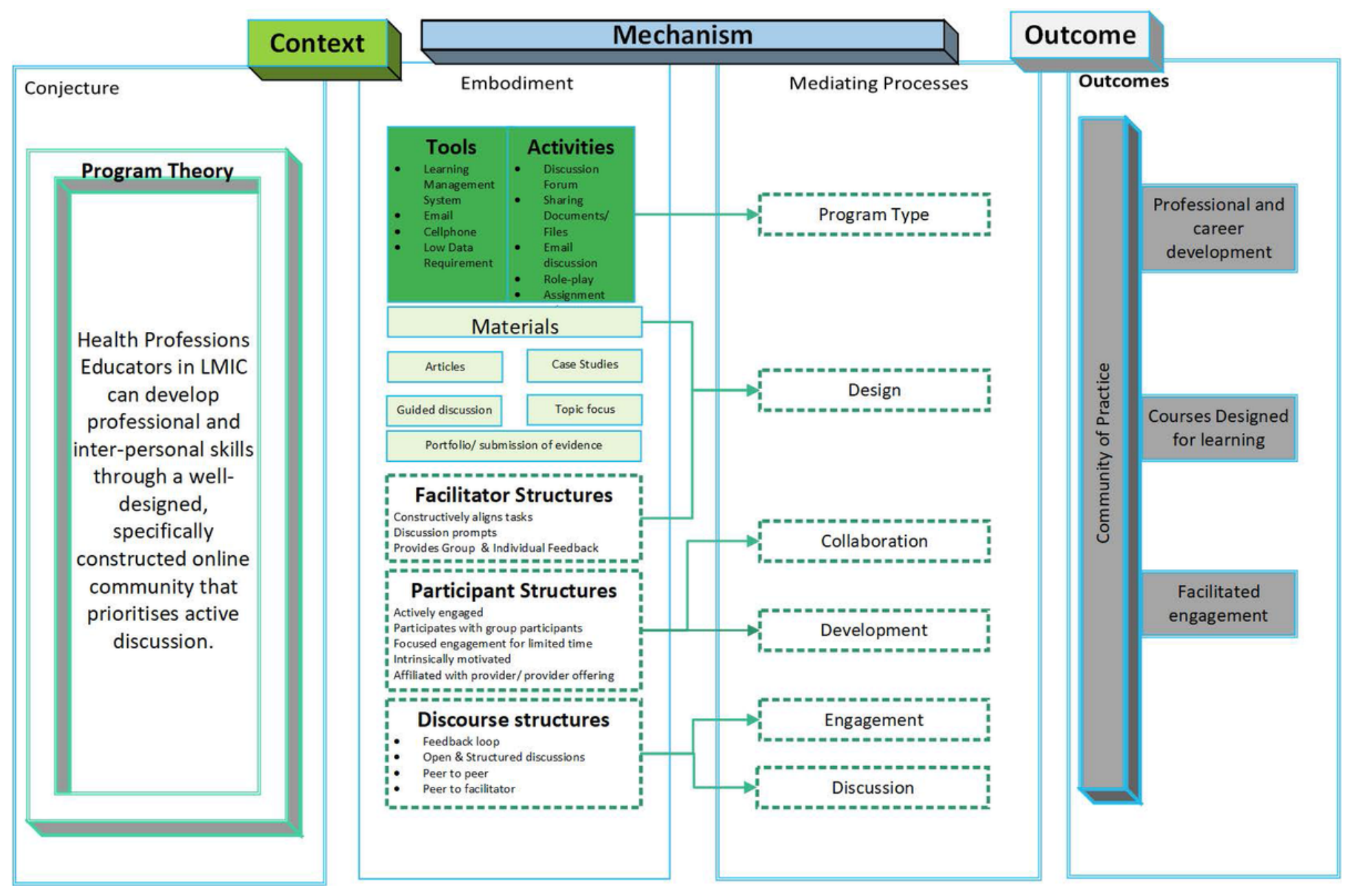

Figure 3

Conjecture Map for online HPE faculty Development

\section{Supplementary Files}

This is a list of supplementary files associated with this preprint. Click to download.

- Additionalfile1.pdf

- Additionalfile2.pdf

- RAMESESStandardsChecklist.docx 